\title{
AKIBAT HUKUM DARI PERCERAIAN TERHADAP ANAK DI BAWAH UMUR DITINJAU MENURUT KITAB UNDANG-UNDANG HUKUM PERDATA DAN UNDANG-UNDANG NOMOR 1 TAHUN 1974 TENTANG PERKAWINAN
}

\author{
Oleh: L. Elly AM Pandiangan \\ elly.pandiangan@uki.ac.id \\ Universitas Kristen Indonesia, Jakarta, Indonesia
}

\begin{abstract}
In accordance with the provisions of the positive law in force, the ownership or acquisition of land with a "DP Nol Rupiah" or without Down Payment is possible and legal according to the agreement of the parties which in practice is mostly done individually, but if the buying and selling activities, however, if the sale and purchase of the house is done through a business entity, then according to the rules in effect the down payment or down payment is a must. It is time for the government to formulate a policy as the realization of the government's rights and guarantees for the provision of decent and healthy housing that can be affordable by all levels of society.
\end{abstract}

Keywords: without down payment; legal according; purchase of the house; formulate a policy .

Pendahuluan

Negara Republik Indonesia sebagai Negara hukum memiliki konstitusi Undang-undang Dasar 1945. Di dalam konstitusi di atur kesetaraan di hadapan hukum (equality before of law), yaitu dalam Pasal 27 yang berbunyi: Segala warga negara bersamaan kedudukannya di dalam hukum dan pemerintahan dan wajib menjunjung hukum dan pemerintahan itu dengan tidak ada kecualinya; Tiap-tiap warga negara berhak atas pekerjaan dan penghidupan yang layak bagi kemanusiaan. ${ }^{1}$

Pada tahun 2002 beberapa pasal Undang-undang Dasar ! 945 telah diamandemen, yaitu Pasal 28 D ayat (1) yang berbunyi "Setiap orang berhak atas pengakuan, jaminan, perlindungan, dan kepastian hukum yang adil serta perlakuan yang sama dihadapan hukum", dan Pasal 281 ayat (2), yang menyatakan: "Setiap orang berhak bebas dan berhak mendapatkan perlindungan terhadap perlakuan yang bersifat diskriminatif itu." 2

Kedua pasal itu menunjukkan bahwa semua warga Negara Indonesia, baik laki-laki maupun perempuan, berkedudukan setara di depan hukum dan dijamin oleh undang-undang.

1 Undang-undang Dasar 1945 Pasal 27.

2 Ibid. Pasal 28D ayat (1) dan Pasal 281 ayat

(2)
Dari penjelasan di atas, secara yuridis formal tidak ada diskriminasi atau ketidakadilan gender bagi perempuan di Indonesia. Akan tetapi, pada tingkat pelaksana Undang-Undang Dasar 1945 perempuan mengalami ketidakadilan gender dalam masalah hukum. Hal tersebut terjadi karena berbagai alasan misalnya belum terdapat petunjuk pelaksanaan prinsip kesetaraan perempuan dan laki-laki di depan hukum. Lebih jauh tingkat pelaksanaan konstitusi akan dijelaskan dalam hukum keluarga mengenai perkawinan.

Perkawinan adalah hubungan antar pribadi yang masuk dalam hukum keluarga di dalam hukum perdata. Menurut Kitab Undang-undang Hukum Perdata (KUHPerdata), pengertian perkawinan dalam Pasal 26: "Undang-undang memandang soal perkawinan hanya dalam hubungan Perdata Perkawinan, menurut KUHPerdata, dipandang dari sudut perdata dan hanya ditinjau dari lembaga hukum, tidak bergantung pada agama, biologi dari calon suami istri.

Sejak diberlakukannya Undang-undang No.l tahun 1974 tentang Perkawinan pada tanggal 2 Januari 1974, maka terciptalah hukum untuk mengatur bidang keluarga yang telah sekian lama didambakan. Dengan demikian warga negara Indonesia, baik pria maupun wanita telah mempunyai landasan yuridis untukmemperolehperlindunganhukum, sebagaimana 
termuat dalam UUD 1945 pasal 27 ayat 1 dan Undangundang No. 1 tahun tentang Perkawinan.

Sebelum lahir Undang-undang No. 1 tahun 1974 yang mengatur tentang perkawinan tersebut, masalahmasalah rumah tangga banyak terjadi karena perlakuan sewenang-wenang oleh suami. Misalnya, jika suami menginginkan perceraian dalam rumah tangganya, hal tersebut bisa terjadi secara mudah. Para istri tidak dapat menolak kesewenangan dari pihak suami dan harus menerima cerai talak yang dijatuhkan kepadanya. Setelah berlakunya Undang-undang No. 1 tahun 1974 tentang Perkawinan, maka perceraian hanya dapat terjadi di depan sidang pengadilan. Jatuhnya putusan perceraian bisa berlaku setelah permohonan perceraian diajukan disertai dengan alasan-alasannya dan pengadilan telah berupaya mendamaikan kedua belah pihak tetapi tidak berhasil. Undang-undang perkawinan diadakan antara lain untuk mencegah perceraian yang sewenang-wenang dari suami.

Tentang perceraian banyak data yang menunjukkan bahwa jumlahnya semakin meningkat. Tingkat perceraian semakin tinggi, bahkan terdapat kecenderungan pihak istri mengajukan cerai gugat lebih besar jika dibandingkan dengan pihak suami.

Fenomena meningkatnya perceraian (cerai gugat) adalah gejala semakin terbukanya kebebasan dan kemandirian perempuan, sedangkan laki-laki(suami) masih mempertahankan dominasinya terhadap istri.

Menurut penelitian, istri yang mengalami perceraian secara otomatis akan menjadi kepala rumah tangga dan juga sebagai pencari nafkah untuk dirinya dan untuk biaya pendidikan anak-anaknya yang diasuhnya. Jika mantan suami tidak memberi nafkah, masalah yang dihadapi istri sebagai kepala rumah tangga cukup berat. Selain secara sosial budaya wanita dianggap sebagai orang kedua setelah pria, juga wanita bertanggung jawab penuh atas kelangsungan hidup rumah tangganya, baik sebagai ibu rumah tangga, sebagai pencari nafkah dan sebagai warga masyarakat (Yusnani, 1999:14). Bertambah berat lagi beban mereka bila melaksanakan cerai gugat, karena semua biaya ditanggung oleh istri (selaku penggugat) yang mengajukan perkara di pengadilan. Di samping itu jika istri yang bekerja sebagai seorang Pegawai negeri Sipil (PNS) mengajukan cerai gugat, maka dia tidak mendapat bagian dari gaji suaminya setelah bercerai.

Jadi masalah yang dihadapi perempuan (istri) dalam mengatasi problem perkawinannya dari berbagai upaya yang dilakukan sampai kepadaupaya terakhir pengambilan keputusan untuk bercerai sangatlah kompleks. Masalah yang sangat kompleks tadi berkaitan dengan faktor eksternal, seperti : anak, suami, masyarakat, lingkungan, dan faktor internal yang berasal dari diri perempuan, antara lain: kemandirian, pengetahuan, pemahaman terhadap masalah dan kesadaran akan hak-haknya. Setelah terjadinya perceraian (kehidupan pasca perceraian), istri berhadapan dengan masalah lain lagi, misalnya : biaya hidup (nafkah), pengasuhan anak-anak, biaya pendidikan, kesehatan dan lain-lain.

Masalah pengasuhan anak-anak akibat dari perceraian orang tuanya menurut Undang-undang Nomor 1 Tahun 1974 Pasal 41 menyebutkan bahwa:

- Baik ibu atau bapak tetap berkewajiban memelihara dan mendidik anak-anaknya, semata- mata berdasarkan kepentingan anak; bilamana ada perselisihan mengenai penguasaan anak-anak Pengadilan memberi keputusannya;

- Bapak yang bertanggung jawab atas semua biaya pemeliharaan dan pendidikan yang diperlukan anak itu; bilamana bapak dalam kenyataan tidak dapat memenuhi kewajiban tersebut. Pengadilan dapat menentukan bahwaibu ikut memikul biaya tersebut;

- Pengadilan dapat mewajibkan kepada bekas suami untuk memberikan biaya penghidupan dan/atau menentukan suatu kewajiban bagi bekas istri. ${ }^{3}$

Dari ketentuan Pasal 41 di atas, secara tegas menjelaskan bahwa hak pengasuhan anak akibat dari perceraian adalah menjadi tanggungjawab kedua orang tuanya, kecuali ada perselisihan maka pengadilan yang memutuskan kepada siapa hak pengasuhan anak itu diberikan. Selanjutnya, dalam memberikan nafkah untuk biaya hidup, kesehatan, dan pendidikan sampai anak itu kawin atau mandiri adalah tanggungjawab suami atau bapaknya. Selain itu, suami juga diwajibkan memberikan nafkah kepada bekas istrinya sepanjang istri masih menjanda atau belum menikah dengan orang lain.

\footnotetext{
3 Undang-undang Nomor 1 Tahun 1974 tentang perkawinan Pasal
} 41 
Permasalahan

Dari uraian di atas penulis merumuskan permasalahan berikut ini:

1. Upaya apa saja yang diambil istri dalam mengatasi masalah rumah tangganya?

2. Faktor-faktor apa saja yang mendorong dan bagaimana proses yang dijalani sampai terjadi cerai gugat?

3. Bagaimana pelaksanaan nafkah istri dan anak serta pengasuhan anak setelah perceraian?

\section{Pengertian Perkawinan Pada Umumnya}

Diantara para sarjana yang mengemukakan pendapatnya mengenai perkawinan yaitu Prof. Dr. Wiryono Prodjodikoro S. H. Yang mengatakan bahwa: "Perkawinan adalah suatu hidup bersama dari seorang laki-laki dan seorang perempuan yang telah memenuhi syarat-syarat yang sudah termasuk dalam peraturan tersebut."

Menurut Kitab Undang-Undang Hukum Perdata (KUH Perdata) tidak menentukan suatu definisi bagi pengertian suatu perkawinan. Dan di dalam pasal 26 KUHPerdata disebutkan bahwa: "UndangUndang memandang perkawinan hanya dari sudut perhubungannya dengan Hukum Perdata". Yang artinya terlepas dari peraturan-peraturan perkawinan diluar Hukum Perdata seperti yang diadakan oleh suatu agama tertentu.

Menurut Undang-Undang No. 1 Tahun 1974 Tentang Perkawinan merupakan kebutuhan hidup seluruh umat manusia. Dan pengertian perkawinan menurut UUP No. 1 Tahun 1974 yang didalamnya terkandung tujuan dan dasar perkawinan yang disebutkan bahwa : "Perkawinan adalah ikatan lahir batin antara seorang pria dengan seorang wanita sebagai suami istri dengan tujuan membentuk keluarga (Rumah Tangga) yang bahagia dan kekal berdasarkan ke-Tuhanan Yang Maha Esa".

Perkawinan yang sah adalah apabila dilakukan menurut hukum masing-masing agamanya dan kepercayaannya itu. Tiap-tiap perkawinan dicatat menurut perundang-undangan yang lama adalah sah.

Maka dari pasal 1 UUP No. 1 tahun 1974 Tentang Perkawinan dan penjelasannya dapat ditarik pengertian:
1. 1) Bahwa perkawinan menurut UU No. 1 Tahun 1974 Tentang Perkawinan adalah berdasarkan keTuhanan Yang Maha Esa.

2. 2) Tujuan perkawinan adalah membentuk dan membina keluarga (Rumah Tangga) yang kekal dan bahagia serta mendapatkan keturunan yang harus dipelihara dan dididik dengan baik.

Agar kebahagiaan sebagaimana yang dikehendaki oleh pasal 1 dapat diwujudkan oleh suami istri maka langkah kearah itu harus di mulai dari awal mereka bersatu, yakni perkawinan.

UU No. 1 tahun 1974 Tentang Perkawinan juga menganut asas-asas atau prinsip-prinsip sebagai berikut:

- Perkawinan itu bertujuan untuk membentuk keluarga yang bahagia dan kekal.

- Perkawinan adalah sah bilamana dilakukan menurut hukum agamanya dan kepercayaan itu.

- Perkawinan harus dicatat menurut peraturan perundang-undangan.

- Calon suami istri harus sudah masak jiwa dan raganya untuk melangsungkan perkawinan.

- Perkawinan berasaskan monogami terbuka.

- Batas umum perkawinan adalah pria 19 tahun dan wanita 16 tahun.

- Perceraian dipersulit dan harus dilakukan dimuka sidang pengadilan.

- Hak dan kedudukan suami istri adalah seimbang.

\section{Akibat Perkawinan Menurut Kitab Undang- Undang Hukum Perdata (KUH Perdata) Atau BW}

1. Hubungan Suami Istri

Suami istri harus saling setia satu sama lain, bantu-membantu, berdiam bersama-sama, saling memberikan nafkah dan bersama-sama mendidik anak-anak kewajiban suami dan istri diatur dalam bab V pasal 103-108 B W. Dan KUH Perdata memulai dengan kaidah bahwa suami dan istri harus saling setia satu sama lain, tolong menolong dan bantu- membantu (pasal 103 B W). Dengan terikatnya suami dan istri dalam perkawinan berarti mereka terikat dalam suatu 
perjanjian secara timbal balik untuk memelihara dan mendidik anak- anak.

2. Anak

a. Anak atau Keturunan

Seorang anak sah (Wetting Kind) adalah anak yang dianggap lahir dari perkawinan yang sah antara ayah dan ibunya. Kepastian seorang anak sungguhsungguh anak ayahnya tentu sukar didapat. Dan menurut pasal 257 ayat (1) BW dijelaskan bahwa seorang suami dapat melakukan pengingkaran, bahwa anak yang dilahirkan istrinya tersebut bukanlah anak sah, dengan ketentuan apabila suami dapat membuktikan bahwa ia sejak 180 hari sampai 300 hari sebelum anak itu lahir tidak mungkin bersetubuh dengan istrinya, oleh karena tidak berkumpul atau dari sebab lain. Ketentuan adanya 180 hari dan 300 hari ini adalah dianggap sebagai batas maksimum tenggang hamil.

b. Anak yang berada dibawah perwalian adalah :

1) Anak sah kedua orang tuanya yang telah dicabut kekuasaannya sebagai orang tua.

2) Anak sah yang orang tuanya telah bercerai.

\section{Akibat Perkawinan Menurut Undang-undang No. 1 Tahun 1974}

1. Hubungan Suami isteri

Dengan adanya suatu perkawinan, maka seorang laki-laki yang menjadi suami memperoleh berbagai hak suami dalam keluarga itu. Begitupun seorang wanita yang mengikatkan diri menjadi istri dalam suatu perkawinan memperoleh berbagai hal pula.

Hak dan kedudukan istri dalam UU No.l tahun 1974 adalah seimbang dengan hak dan kedudukan suami dalam kehidupan rumah tangga dan pergaulan hidup bersama dalam masyarakat.

Dalam UU No.1 tahun 1974 Tentang Perkawinan dikatakan bahwa suami kepala keluarga dan istri adalah ibu rumah tangga, jadi antara suami dan istri mereka harus saling setia satu sama lain, tolong menolong, bantu membantu dan memberikan bantuan lahir batin antara yang satu kepada yang lain.

\section{Anak Atau Keturunan}

Hak kedudukan anak diatur pada pasal 42. 43 dan 44 UUP No.l tahun 1974 Tentang Perkawinan. Anak yang sah adalah anak yang dilahirkan dalam atau sebagai akibat perkawinan yang sah.

Anak yang dilahirkan diluar perkawinan hanya mempunyai hubungan perdata dengan ibu dan keluarga ibunya. Seorang suami dapat menyangkal sahnya anak yang dilahirkan oleh istrinya, bilamana ia dapat membuktikan bahwa istrinya telah berzinah dan anak itu akibat dari pada perzinahan itu. Yang dapat memutuskan sah atau tidaknya anak tersebut adalah pengadilan atas permintaan pihak yang berkepentingan.

Dalam UUP No.l tahun 1974, anak yang sah adalah anak yang lahir dalam atau sebagai akibat peerkawinan yang sah. Jadi kalau seorang wanita yang telah mengandung karena berbuat zinah dengan orang lain, kemudian ia kawin secara sah dengan pria yang bukan pemberi benih pada kandungan wanita tersebut maka jika anak itu lahir maka anak itu adalah anak sah dari perkawinan wanita tersebut dengan pria itu.

\section{Pembuktian Asal Usul Anak}

Pembuktian asal usul anak dapat dibuktikan dengan akte yang dikeluarkan oleh pejabat yang berwenang. Bila akte kelahiran tersebut tidak ada maka pengadilan dapat mengeluarkan penetapan asal-usul anak setelah diadakan pemeriksaan yang teliti berdasarkan buktibukti yang telah memenuhi syarat. Pembuktian bahwa asal usul seorang anak ditentukan pada pasal $55 \mathrm{UU}$ No.l tahun 1974 Tentang Perkawinan.

Pencabutan kekuasaan orang tua salah seorang atau kedua orang tua dapat dicabut kekuasaannya terhadap seorang anak atau lebih untuk waktu tertentu. Yang dimaksud dengan kekuasaan ini tidak termasuk kekuasaan sebagai wali nikah, pencabulan tersebut ditetapkan dengan putusan pengadilan dalam hal :

- Orang tua melalaikan kekuasaannya terhadap anaknya.

- Orang tua berkelakuan buruk sekali.

- Yang dapat mengajukan permintaan pencabutan kekuasaan orang tua ialah orang tua yang lain, keluarga anak dalam garis lurus keatas dan saudara kandung yang telah dewasa atau pejabat yang berwenang. 


\section{Perwalian}

Perwalian pada UUPNo. I tahun 1974 adalah kedua orang tuanya yang semata-mata demi kepentingan si anak, meskipun de Facto pelaksanaannya hanya dijalankan oleh salah seorang dari mereka.

Hal ini berarti bahwa seperti halnya menurut KUHPerdata bahwa antara si anak dengan orang tua yang De Fakto tidak menjalankan kekuasaan atas diri si anak tetapi tetap terjalin hubungan lahir batin, dalam hal itu mempunyai pengaruh yang baik terhadap pertumbuhan pribadi si anak yang tidak akan begitu terasa oleh si anak bahwa ada perubahan dalam status hubungan orang tuanya. Dan UUP ini akan lebih mampu menjalankan pertumbuhan pribadi si anak secara positif.

Mengenai perwalian ini diatur pada pasal 49-54 UUP No.l tahun 1974 Tentang Perkawinan yaitu :

- Anak di bawah perwalian (pasal 50)

- Anak yang belum mencapai umur 18 tahun atau belum pernah melangsungkan perkawinan, dan yang berada dibawah kekuasaan orang tua, serta berada dibawah kekuasaan wali. Dan perwalian itu berlaku bagi diri si anak maupun harta si anak.

- Orang-orang yang diangkat menjadi wali atas anak di bawah umur (pasal 49 dan pasal 51)

Pasal 49 aayat (1) UUP No.l tahun 1974 mengatur mengenai perwalian yang berada di bawah kekuasaan orang tua dan yang diatur perwaliannya secara sah akan ditunjuk seorang wali oleh pengadilan. Hakim akan mengangkat seorang wali setelah mendengar permintaan orang tua yang lain, keluarga anak dalam garis lurus keatas dan saudara kandung yang telah dewasa atau pejabat yang berwenang yang dikarenakan salah seorang atau kedua orang tua melalaikan kewajibannya terhadap anaknya dan berkelakuan buruk sekali. Sedangkan dalam pasal 51 ayat (1) dan (2), wali dapat ditunjuk oleh satu orang tua yang menjalankan kekuasaan orang tua sebelum ia meninggal, dan dengan surat wasiat atau dengan lisan dan juga harus dihadapkan 2 orang saksi, maka wali sedapat-dapatnya diambil dari keluarga anak atau orang lain yang sudah dewasa, berpikiran sehat, adil, jujur, dan berkelakuan baik. Bila kekuasaan wali tersebut dicabut maka pengadilan menunjuk orang lain sebagai penggantinya.

\section{Kewajiban Wali [pasal 51 ayat $(3,4$ dan 5)]}

- Wajib mengurus anak dan harta di bawah perwaliannya dengan sebaik-baiknya dengan menghormati agama dan kepercayaan anak tersebut.

- Membuat daftar harga dan mencatat perubahanperubahan dan kepercayaan anak itu.

- Bertanggung jawab atas harta kekayaan dan menanggung kerugian yang timbul karena kesalahan atau kelalaiannya.

- Wali tidak diperbolehkan memindahkan hak atau menggadaikan barang-barang tetap milik anak kecuali apabila ada kepentingan anak itu menghendaki.

\section{Peraturan dan Pandangan Tentang Per- ceraian}

Di Indonesia untuk melaksanakan perceraian secara baik-baik melalui tahapan (pendamai) yang diatur oleh pemerintah dengan melalui Majelis Hakim dalam persidangan di Pengadilan Agama. Hal ini dimaksudkan disamping harus meneliti sahihnya atau kebenaran dari bukti- bukti, juga memberikan kesempatan masing-masing pihak untuk mempertimbangkan dan memikirkan kembali gugatannya.

Alasan-alasan yang dapat menyebabkan terjadinya Perceraian Undang-undang No. 1 tahun 1974 tentang Perkawinan telah mengatur, bahwa dalam mengajukan gugatan perceraian kepada pengadilan haruslah disertai alasan. Pasal 39 Undang-undang No. 1 Tahun 1974 tentang perkawinan ditentukan bahwa :

- Perceraian hanya dapat dilakukan di depan Sidang Pengadilan, setelah pengadilan yang bersangkutan berusaha dan tidak berhasil mendamaikan kedua belah pihak.

- Untuk melakukan perceraian harus ada cukup alasan, bahwa antara suami-istri itu tidak akan dapat hidup rukun sebagai suami-istri.

- Tata cara perceraian di depan sidang pengadilan diatur dalam peraturan perundang-undangan tersendiri.

Menurut penjelasan pasal 39 ayat (2) adalah sebagai berikut : alasan-alasan yang dapat dijadikan dasar untuk perceraian adalah : 
- Salah satu pihak berbuat zina atau menjadi pemabok, pemadat, penjudi dan lain sebagainya yang sukar disembuhkan.

- Salah satu pihak meninggalkan yang lain selama dua tahun berturut-turut tanpa izin pihak yang lain dan tanpa alasan yang syah atau karena hal lain di luar kemauannya.

- Salah satu pihak mendapat hukuman penjara lima tahun atau hukuman yang lebih berat setelah perkawinan berlangsung.

- Salah satu pihak melakukan kekejaman atau penganiayaan berat yang membahayakan terhadap pihak lain.

- Salah satu pihak mendapat cacat badan atau penyakit yang mengakibatkan tidak dapat menjalankan pekerjaannya sebagai suami atau istri.

- Antara suami-istri terus menerus terjadi pertengkaran dan tidak ada harapan akan hidup rukun lagi dalam rumah tangga.

Di dalam KUH Perdata putusnya perkawinan dipakai dengan istilah pembubaran, perkawinan. Menurut KUH Perdata perkawinan itu bubar dikarenakan oleh : kematian, tidak hadirnya suami atau istri selama sepuluh tahun yang diiringi perkawinan baru istri atau suami, keputusan hakim setelah pisah meja dan ranjang dan pendaftaran pemutusan perkawinan dalam daftar catatan sipil dan karena perceraian (Pasal 199).

Dasar-dasar yang dapat berakibat perceraian perkawinan adalah sebagai berikut:

- Zina

- Meninggalkan tempat tinggal bersama dengan itikad buruk

- Dikenakan hukuman penjara lima tahun atau hukuman yang lebih berat lagi setelah dilangsungkannya perkawinan.

- Pencederaan berat atau penganiayaan, yang dilakukan oleh salah seorang suami - istri terhadap yang lainnya sedemikian rupa, sehingga membahayakan keselamatan jiwa atau mendapatkan luka-luka yang berbahaya (Hilman Hadikusuma, 1990: 161).

\section{Analisis Kasus}

Berdasarkan sumber data berupa putusan Nomor 302/PDT.G/2004/PN.Bks (Lampiran 1) pengadilan tingkat pertama, diperoleh data yang menunjukkan bahwa pada tanggal 11 Nopember 2000 telah terjadi pernikahan antara penggugat Cintya Dian Astuti (perempuan) dan tergugat Andreas Heru Prakoso ¡laki-laki), dan perkawinan tersebut tercatat pada Kantor Catatan Sipil Jakarta Pusat pada tanggal 13 Nopember 2000 sesuai Kutipan Akta Nomor 318/ UJP/2000. Untuk memperkuat perkawinan tersebut secara agama Katholik, pada tanggal 11 Nopember 2000 dilakukan upacara perkawinan secara Katholik di Gereja Katholik Katedral, Jakarta Pusat. Dari hasil perkawinan antara penggugat dan tergugat diperoleh dua ;-rang anak, yaitu Maria Jezzica Oktaviane, lahir di Jakarta, tanggal 22 Oktober 2001 sesuai Kutipan Akta Kelahiran Nomor : 559 U/JT/2001 dan Nickolas Delfino Abunanyu, lahir di Jakarta, tanggal 3 Juni $2003 \mathrm{~s}$ e s u a i dengan Kutipan Akta Kelahiran Nomor 1.151/U/JT/2003, yang mana Akta Kelahiran keduanya yang dikeluarkan oleh Kantor Catatan Sipil kotamadya Jakarta Timur.

Pada awalnya perkawinan rumah tanggal penggugat dan tergugat berjalan baik dan harmonis, walaupun ada pertengkaran kecil, "hal ini dianggap penggugat sebagai hal yang biasa dalam suatu perkawinan". Pada saat itu penggugat dan tergugat tinggal di kediaman orang tua penggugat. Namun, sejak bulan Januari 2001 perkawinan penggugat dan tergugat menjadi kurang 'harmonis. Awal kejadian pada bulan Nopember 2001 bermula "bahwa tergugat dalam keadaan marah, mengambil dan membawaperabotan kamar termasuk tempat tidur dan lain-lain untuk pindah rumah dari kediaman orang tua penggugat yang selama ini mereka tempati”. Setelah pindah ke rumah yang baru di Jalan Alamanda 2 Nomor 14 Rt.008/07 Kelurahan Jatiwaringin, Pondok Gede, keributan dan percekcokan terus menerus terjadi. Selain itu, tergugat juga sering memukul, menonjok, bahkan sering meminta penggugat untuk pulang kerumah orang tua penggugat, dan mengusir sambil membuang-buang pakaian penggugat, padahal saat itu penggugat dalam keadaan hamil, sehingga akibat dari perbuatan tergugat menyebabkan penggugat menderita lahir dan batin.

Pertengkaran yang lebih tragis terjadi pada tanggal 6 April 2002, tergugat melakukan penganiayaan dengan memukul mata sebelah kiri penggugat, sehingga mata sebelah kiri penggugat bengkak, merah dan ada luka di bagian dalam mata tersebut. Penggugat dengan di antar oleh kakak sepupunya di 
bawa ke Rumah Sakit Harum, tetapi penggugat tidak melaporkan penganiayaan tergugat ke kepolisian. Namun, pada tanggal 22 Agustus 2004, terjadi lagi pertengkaran dan tergugat melakukan penganiayaan. Atas penganiayaan tersebut, kemudian penggugat melaporkannya ke Polsek Metro Pondok Gede sesuai dengan Surat Tanda Penerimaan Laporan Pemohon Nomor Pol. LP/l 66-PG/K/VIIl/04\RES.BKS tanggal 22 Agustus 2004 dan sekaligus dibuatkan visum di R. S. Haji Pondok Gede. Kemudian, atas saran pihak Polisi, "penggugat diharapkan dapat pulang ke rumah orang tua demi keselamatan jiwanya". Kejadian yang dialami ini menunjukkan relasi kekuasaan suami terhadap istrinya.

Kemudian, "karena penggugat merasa khawatir dengan ancaman tersebut akhirnya penggugat pergi ke rumah orang tuanya hingga sekarang, ia sebagai istri tidak tahan karena sering dianiaya, maka ia pergi dengan kedua anaknya meninggalkan suami. Usaha berdamai juga sudah dilakukan oleh orang tua penggugat akan tetapi tidak membuahkan hasil yang positif.

Bahasa perempuan ini menjelaskan penderitaan yang dialaminya sebagai bentuk suara perempuan yang harus didengar. Secara jelas dan langsung ia mengatakan "sudah tidak senang lagi bersuamikan tergugat dikarenakan perbuatan tersebut di atas". Mengajukan perkara cerai gugat ini, bagi perempuan umumnya adalah tidak mudah. Karena status janda dan masalah ekonomi merupakan masalah tersendiri yang harus dihadapi perempuan. Dalam kajian perempuan, penting sekali menanyakan keinginan atau perspektif perempuan korban itu sendiri dan menjelaskan konsekuensi yang akan diterimanya.

Akhirnya, karena sudah berpisah rumah dengan suami, demi kepastian hukum status perkawinannya, penggugat memutuskan untuk menggugat cerai dan hak asuh pengasuhan kedua anaknya ke pengadilan. Dengan alasan Pasal 19 point (f), Peraturan Pemerintah Nomor 10 Tahun 1975 dikatakan "bahwa perceraian dapat terjadi karena antara suami dan istri terus menerus terjadi perselisihan dan pertengkaran dan tidak ada harapan akan hidup rukun lagi dalam rumah tangga."

Dari kutipan di atas, dapat dikatakan bahwa telah terjadi semua yang memenuhi maksud dalam pasal tersebut, malah dapat dikatakan telah terjadi tindak kekerasan dalam rumah tangga. Apa yang dialami oleh penggugat harus dilaporkan menjadi delik aduan dalam peristiwa pidana. Di samping itu, gugatan penggugat ini menunjukkan penderitaan yang dialaminya akibat ulah suami. Keputusan meninggalkan rumah tanpa membawa apa-apa bukanlah hal yang mudah. Tentu ada pergulatan batin, dan perempuan sering mengalah untuk keselamatan yang lebih besar. Ini dapat dilihat dari permintaan penggugat untuk mengasuh anaknya.

Putusan hakim nomor 302/PDT.G/2004/PN.Bks, berisi pertimbangan hakim dalam jawaban tergugat "Bahwa penggugat pada gugatannya tidak jelas mengenai obyek yang dipermasalahkan apakah gugatan perceraian ini didasarkan pada penganiayaan, ketidak harmonisan rumah tangga atau hal-hal lainnya yang menjadi alasan oleh hukum dibenarkan sebagai alasan perceraian".

Pertimbangan hakim dalam duplik "Tentang tidak jelasnya obyek yang dipermasalahkan, majelis hakim menyatakan bahwa masalah gugatan telah diatur dengan jelas didalam Pasal 118 HIR dan 142 Rbg yang isinya adalah gugatan harus memuat : a) Fundamentum petendi atau identitas pihak penggugat dan Tergugat; b) harus ada posita atau dasar gugatan misalnya wanprestasi, perbuatan melawan hukum, perceraian, dan lain-lain; c) harus ada petitum atau tuntutan, misalnya pembayaran sejumlah uang, tuntutan ganti rugi, dan lain-lain; d) harus ditanda tangani penggugat. Setelah majelis kalam memperhatikan dengan seksama ternyata seluruh persyaratan yang diperintahkan oleh kedua pasal yaitu Pasal 118 HIR dan 142 Rbg telah dipenuhi dalam gugatan penggugat, dan oleh karenanya eksepsi tergugat dalam hal ini lurus ditolak.

Duplik tergugat dalam pokok perkara. menjelaskan bahwa seolah-olah tidak pernah terjadi kekerasan terhadap penggugat. Tergugat sangat pandai menyusun duplik ini untuk mendapatkan simpati dari majelis hakim. Dapat dibaca bahwa tergugat menolak semua yang didalilkan oleh penggugat dan mencari pembenaran bagi dirinya, seperti "Tergugat sering memukul apalagi menonjok penggugat, bahkan sebaliknya penggugat sendiri yang tidak lain adalah seorang wanita, seorang isteri dan seorang ibu, sering melakukan tindakan kekerasan dengan melakukan penamparan dan melempar sesuatu kepada tergugat dan selalu bicara kasar dengan mengatakan : 'ingin bercerai dengan tergugat'; 'sudah tidak ingin tinggal dengan tergugat'; 'tergugat tidak berhak atas anak- 
anak karena penggugatlah yang melahirkan anakanak". Atas peristiwa tersebut, tergugat tidak pernah melaporkan hal-hal tersebut kepada orang lain apalagi kepada pihak berwajib, dengan alasan untuk menjaga nama baik bersama (penggugat dan tergugat).

Pertimbangan hakim dalam duplik "tentang terjadinya pertengkaran dan penganiayaan terhadap penggugat oleh tergugat", dengan bukti-bukti berupa Surat Tanda Penerimaan Laporan No.Pol. : LP/

/166-PG/K/VIII/04/RES.BKS, yang berisi laporan penggugat tentang penganiayaan kepada Polsek Pondok Gede, berupa kerugian korban mengalami luka memar di bagian sikut tengah sebelah kiri akibat kena benturan tembok akibat didorong tergugat; dan Visum Et Repertum yang dikeluarkan oleh R.S. Haji Pondok Gede No. 067/RSHJ/VER/VII/2004 tanggal 22 Agustus 2004 yang berisi keterangan tentang adanya luka lecet dan memar di siku kiri 1/4 X $1 / 4 \times 1 / 2$ $\mathrm{cm}$; serta diperkuat dengan bukti berupa Berita Acara Pemeriksaan Tersangka (tergugat) yang dibuat oleh Polsek Pondok Gede tanggal 15 September 2004, yang menerangkan bahwa benar saat ini saya (tergugat) telah cekcok atau rebut dengan istri saya (penggugat). Dalam keterangannya tergugat mengatakan, "Istri saya (penggugat) diam saja dan tidak melepaskan anak saya dan tetap menggendongnya, sehingga anak saya menangis, saya (tergugat) berusaha merebut anak saya dari gendongan istri saya sampai akhirnya terjadi saling tarik menarik anak antara saya dan istri saya, namun akhirnya anak bisa saya rebut dari tangan istri saya dan saat itu karena terjadi saling tarik tersebut,' dan setelah anak terlepas dari istri saya secara tiba-tiba istri saya sempat terpental ke belakang secara tidak sengaja dan tubuh istri saya mengenai dinding yang jaraknya kurang lebih $40 \mathrm{~cm}$ dari posisi istri saya berdiri". Hal ini telah membuktikan bahwa tergugat jelas telah melakukan penganiayaan terhadap penggugat.

Pertimbangan hukum hakim di atas, juga merupakan beban pembuktian terhadap tuntutan yang didalilkan oleh penggugat yang menjadi pertimbangan majelis hakim dalam memutuskan perkara ini. Dalam pemeriksaan, majelis hakim mendapatkan bukti-bukti berupa P.4 dan P.5 mempunyai kekuatan pembuktian yang sempurna dengan demikian penggugat telah dapat membuktikan dalilnya.

Dari analisis di atas, jelas sekali peran aktif majelis hakim memberikan pertimbangan hukum demi kepentingan penggugat menunjukkan keberpihakannya pada perempuan. Hal ini juga dalam pertimbangan lainnya yaitu "Bahwa saksi- saksi Ny. A, Ny. RL, dan EDP, menerangkan bahwa penggugat dan tergugat telah terjadi percekcokan yang terus menerus yang sudah tidak dapat didamaikan lagi bahkan telah melibatkan rohaniawan, akan tetapi juga tidak berhasil". Cuplikan keterangan saksi ini mempertimbangkan bahwa kehidupan rumah tangga penggugat dan tergugat sudah tidak harmonis lagi.

Pertimbangan hukum dari hakim menunjukkan fakta bahwa dalam pemeriksaan cerai gugat ini telah terjadi kekerasan secara ekonomis, psikis dan fisik seperti yang disampaikan oleh penggugat dan menjadi pertimbangan hukum di atas. Kekerasan yang dialami oleh penggugat secara fisik harus dilaporkan kepada aparat hukum menjadi delik aduan dalam peristiwa hukum pidana, sementara itu perceraian adalah peristiwa perdata. Tindakan kekerasan tersebut dalam pertimbangan hukum hakim ditafsirkan dengan kata "percekcokan" yang memenuhi unsur alasan perceraian sesuai dengan Undang-undang Nomor 1 Tahun 1974 Pasal 19 huruf (i) yang menjelaskan bahwa perceraian dapat terjadi karena atau alasan "antara suami dan istri terus menerus terjadi perselisihan dan pertengkaran dan tidak ada harapan akan hidup rukun lagi dalam rumah tangga". Padahal seharusnya hakim sebagai aparat hukum bertindak bahwa telah terjadi penganiayaan dan mengancam keselamatan perempuan. Karena, perceraian peristiwa perdata, sedangkan kekerasan peristiwa pidana, sikap hakim mengikuti peraturan asas legalitas. Jadi hakim tidak memberikan sanksi langsung terhadap pelaku tindak kekerasan tersebut, karena hakim juga terikat dengan tidak boleh melebihi isi tuntutan gugatan penggugat.

Perkawinan antara penggugat dan tergugat putus karena perceraian, selanjutnya majelis hakim mempertimbangkan mengenai siapakah sebaiknya diantara penggugat dan tergugat yang akan mengasuh anak dan menjadi wali anak-anak mereka. Pertimbangan hukum hakim terhadap masalah ini adalah sebagai berikut : "Menimbang, bahwa berdasarkan ketentuan Pasal 40 huruf a Undang-undang Nomor 1 Tahun 1974 tentang Perkawinan maka akibat putusnya perkawinan maka anak-anak yang lahir dalam perkawinan tersebut baik bapak maupun ibunya tetap berkewajiban memelihara dan mendidik anak-anaknya semata-mata berdasarkan untuk kepentingan anak, dan apabila ada perselisihan mengenai penguasaan tentang anak-anak 
maka Pengadilan dapat memberikan putusannya; dan apabila dihubungkan ketentuan Pasal 45 Undangundang Nomor 1 Tahun 1974 bahwa kedua orang tua wajib memelihara dan mendidik anak-anak mereka sebaik-baiknya dan bila dihubungkan dengan Pasal 47 Undang-undang Nomor 1 Tahun 1974 bahwa anak yang belum dewasa atau belum mencapai 18 tahun ada dibawah kekuasaan orang tuanya".

Keputusannya, "Menimbang, bahwa berdasarkan isi dan uraian ketiga pasal tersebut di atas, yaitu Pasal 40 huruf a, Pasal 45 dan Pasal 47 Undang-undang Nomor 1 Tahun 1974 tentang Penguasaan anakanak yang masih dibawah umur dibawah kekuasaan orang tuanya saja, maka majelis hakim mengikuti yurisprudensi tetap Mahkamah Agung Republik Indonesia untuk kepentingan anak-anak yang belum dewasa pemeliharaannya atau penguasaannya diserahkan kepada ibunya. Dengan demikian petitum penggugat dikabulkan. Artinya hak pengasuhan kedua anak hasil perkawinan penggugat dan tergugat, diserahkan kepada penggugat sampai kedua anak tersebut hidup mandiri.

Selanjutnya hakim akan menimbang tuntutan nafkah bagi penggugat dan kedua anaknya dengan dasar hukum yaitu Pasal 45 Undang-undang Nomor 1 Tahun 1974, "bahwa mengenai beban dan tanggung jawab untuk kebutuhan sehari-hari seperti biaya hidup, biaya sekolah, dan kesehatan dibebankan kepada tergugat yang besarnya Rp. 2.000.000,(dua juta rupiah) setiap bulannya harus diserahkan kepada penggugat. Dalam masalah ini hakim mempertimbangkan bahwa tergugat sampai perkara ini disidangkan dan diputuskan masih bekerja di Bank Niaga Jakarta, sehingga tuntutan penggugat dimaksud dikabulkan. Dasar hukum ini cukup adil, hanya bagaimana mengawasi pelaksanaannya dan sanksi apa jika tidak melaksanakan tidak diatur. Artinya harus ada gugatan baru lagi yang akan memakan waktu sementara kebutuhan harus segera dipenuhi.

Dalam pemeriksaan pengadilan tingkat pertama ini, yang diputuskan pada tanggal 11 Januari 2005 dengan Putusan No. 302/PDT.G/2004/PN.Bks, yang terdiri dari tiga orang hakim laki-laki dalam pertimbangan hukumnya adalah "sudah tepat dan benar" dan "harus dikuatkan".
Kesimpulan dan Saran

Analisis putusan hakim yang memfokuskan pada masalah hukum menunjukkan bahwa pertama, persoalan perempuan sudah diangkat ke permukaan dan menjadi masukan bagi sistem hukum yang berlaku dalam rangka reformasi hukum. Dalam hal ini, yang penting bukan masalah menang atau kalah dalam berperkara. Kedua, dalam sistem hukum Eropa Kontinental (civil law system) yang menggunakan hukum tertulis atau juga disebut kodifikasi, penafsiran aparat hukum hanya pada pemenuhan unsur dalam pasal. Padahal, kodifikasi tidak boleh kaku karena masalah hukum yang terjadi dalam masyarakat mungkin belum tertampung di dalamnya. Misalnya untuk menyelesaikan masalah penghargaan, kerugian materiil, dan penderitaan immaterial para korban perempuan, tidak ada peraturan yang menjadi tolak ukur.

Pada perkara ini, masalah perceraian adalah peristiwa perdata, tetapi di balik itu terjadi peristiwa pidana yang masuk dalam delik aduan. Karena peraturan pidana yang sangat legalistis maka hakim terikat dengan aturan prosedur yang berlaku dalam menangani perkara pidana, dalam pemeriksaan perkara kekerasan dalam rumah tangga. Pertimbangan hukum hanya terpaku pada memenuhi unsur pasal gugatan atau dakwaan saja.

\section{Saran}

Analisis menunjukkan bahwa ada beberapa peraturan yang melindungi perempuan sedikit banyak belum disentuh oleh majelis hakim, sehingga perlu sosialisasi. Juga disarankan untuk melakukan sosialisasi kepada aparat hukum tentang hukum berspektif gender. 


\section{DAFTAR PUSTAKA}

Abdulkadir Muhammad, 1993, Hukum Perdata Indonesia, PT Citra Aditya Bakti, Bandung

Amal. Siti Hidayati (1995), Penelitian Yang Berspektif Wanita, dalam TO Ihromi, Kajian Wanita Dalam Pembangunan (h. 110-131), Jakarta, Yayasan Obor Indonesia.

Anastasia dan Lugina Setyawati (Ed) (1992) Penelitian yang berwawasan Wanita, Jakarta, Proyek Studi Pembangunan FISIP U.I.

A. Rifai Mien (1997) Pegangan Penulisan Penyuntingan dan Penerbitan Karya Ilmiah Indonesia, Yogyakarta Gajahmada University Press.

Bakry, Hasbullah (1985) Kumpulan Lengkap Undangundang dan Peraturan Perkawinan di Indonesia. Jakarta; Djambatan.

Hadikusuma, Hilman H, Hukum Perkawinan Indonesia Menurut Perundangan, Hukum Adat, dan Hukum Agama, Bandung : Mandar Maju, 1990.

Hidayat, Rahayu. S dan E, Kristi Poerwandari, (2000) Perempuan Indonesia dalam Masyarakat yang Tengah Berubah, Jakarta : Program Studi Kajian Wanita Program Pascasarjana Universitas Indonesia.

Ihromi, T.O (Peny.) (1995) Kajian Wanita dalam Pembangunan. Jakarta : Yayasan Obor Indonesia.

Ihromi, T.O, Irianto, Sulistyowati, Sudiarti Achie (Peny.) (2000), Penghapusan Diskriminasi Terhadap Wanita, Bandung, Alumni.

Komite Nasional Kedudukan Wanita Indonesia (KNKWI) dan Departemen Luar Negeri RI (t.t) Undang-undang No. 7 Tahun 1984 Tentang Pengesahan Konvensi Mengenai Penghapusan Segala Bentuk Diskriminasi Terhadap Wanita (CEDAW), Jakarta, Kantor Menteri Negara Urusan Peranan Wanita.

Murata, Sachico (1999) The Tou Of Islam : Kitab Rujukan Tentang Relasi Gender dalam Kosmologi dan Teologi Islam, Astuti, Rahmani, dan Nasrullah (Penerj.), Bandung, Mizan.

Moh Nazir, Ph D (2001) Metodologi Penelitian, Ghalia Indonesia.

Rahima (2001) Perempuan, Perkawinan dan Rumah Tangga (koleksi kliping), Jakarta, PusatPelatihan dan informasi Islam dan Hak-hak Perempuan.

Rahman, Anita (2000), dalam Poerwandari, E. Kristi dan Surtiyati Hidayat, Rahayu (Ed) Perempuan Indonesia dalam Masyarakat Yang Tengah Berubah (h 325-343), Jakarta, Program Studi Kajian Wanita PPs U.I.

Saptari, Ratna dan Holzner, Brigitte (1997) Perempuan Kerja dan Perubahan Sosial, Sebuah Pengantar Studi Perempuan, Jakarta, Pustaka Utama Grafiti.

Sarjono Hr dan Darmabrata Wahyono, (1998) Perbandingan Hukum Perdata Masalah Perkawinan, Ghalia Indonesia, Jakarta.

Sudarsono, Hukum Perkawinan Nasional, 2005, cet.3, Jakarta, PT. Asdimahasatya

Syahrani, Riduan (1987) Perkawinan dan Perceraian Bagi Pegawai Negeri Sipil, Jakarta, Media Sarana Press.

Sukardja, Ahmad (2001) Hukum Keluarga dan Peradilan Keluarga di Indonesia, Jakarta. Mahkamah Agung R.I.

Perundang-Undangan:

Undang-Undang Dasar 1945 setelah amandemen keempat Tahun 2002 dan GBHN 1999 - 2004, penerbit Pustaka Setia, Cetakan keempat Revisi, Bandung 2002.

Undang-Undang Nomor 14 Tahun 1970 tanggal 17 Desember 1970 tentang Ketentuan-Ketentuan Pokok

Kekuasaan Kehakiman jo Undang-Undang Nomor 35 Tahun 1999. 
Undang-Undang Nomor 1 Tahun 1974 tentang Perkawinan.

Undang-Undang Nomor 7 Tahun 1984 tentang Pengesahan Konvensi mengenai Penghasilan Segala Bentuk Diskriminasi Terhadap Perempuan.

Kitab Undang-undang Hukum Perdata., R Subekti \& R Tjitrosudibio, PT Pradnya Paramita, 2005, Jakarta.

Undang-Undang No 39 Tahun 1999 tentang Hak Asasi Manusia.

Undang-Undang No 23 Tahun 1999 tentang Penghapusan Kekerasan Dalam Rumah Tangga. 